Yayın Geliş Tarihi: 05.03.2012

Yayına Kabul Tarihi: 08.07.2014

Online Yayın Tarihi: 30.09 .2014
Dokuz Eylül Üniversitesi

Sosyal Bilimler Enstitüsü Dergisi

Cilt: 16, Say1: 2, Y11: 2014, Sayfa: 235-257

ISSN: 1302-3284 E-ISSN: 1308-0911

\title{
RECONCILIATION UNDER THE SHADOW OF DIASPORA POLITICS: SOME LESSONS FROM THE TURKISH-ARMENIAN RECONCILIATION COMMISSION (TARC)
}

\begin{abstract}
Nazif MANDACI ${ }^{*}$

Reconciliation is beyond diplomatic rapprochement and consequently strategic partnership in its maxim. It is irrelevant to transaction costs; moreover, "independent from them" since it is normative-oriented. Literature of reconciliation contains some concepts which cannot be "appreciated", literally, in diplomatic realm, such as forgiving and forgetting, having theological connotations. To the contrary, international relations literature generally accept that "primordial factors like ethnicity and religion had no part in rational explanations for the way the world works"(Fox and Sandler 2004: 9); and nobody appreciates any political decision that sacrifices national interest on the altar of virtue. This study aims at elaborating on the Turkish-Armenian Reconciliation Commission which Turkey and Armenia had formed in 2001 within the framework of the aforementioned arguments.
\end{abstract}

Keywords: Reconciliation, TARC, Diaspora.

\section{DIYASPORA SIYYASETİ GÖLGESINDE UZLAŞMA: TÜRK-ERMENI UZLAȘMA KOMISYONU'NDAN BAZI DERSLER}

$\ddot{O} z$

Uzlaşma süreçleri diplomatik yakınlaşmalar ve en azamisinden stratejik ortaklıkların çok ötesindeki durumsallıkları ifade etmektedir. Normatif yönlü olduklarından diplomatik anlamda ilişki kurmanın beraberinde getirebileceği maliyetlerden tamamıla bağımsızdırlar. Uzlaşma literatürü diplomatik platformda genel olarak önemsenmeyen, hatta ötesinde teolojik yönü bile bulunan bağışlamak ya da affetmek gibi kavramlara yer vermektedir. Bunun tersine uluslararast ilişkiler literatürüne bakıldığında etnisite ya da din gibi primordiyal faktörlerin dünyada işlerin nasıl yürüdüğ̈̈ne dair akılcı açıklamalar içinde kendilerine pek yer bulamadıklarl gözlemlenmektedir (Fox ve Sandler, 2004: 9). Dahası, kimse ulusal çıkarları erdemlilik altarında feda edecek politik kararları onaylamamaktadır. Bu çalışma, Türkiye ve Ermenistan arasında 2001 yılında oluşturulan Türk-Ermeni Uzlaşma Komisyonu'nu bu çerçeve içinde değerlendirmeyi amaçlamaktadır.

Anahtar Kelimeler: Uzlaşma, TARC, Diaspora.

* Prof. Dr., Yaşar University, Faculty of Economic and Administrative Sciences, Department of International Relations, nazif.mandaci@yasar.edu.tr 


\section{INTRODUCTION}

Turkey and Armenia have a long history of feud that plagued both parties respectively in political and economic terms. Despite terrorist attacks that targeted Turkish diplomatic corps abroad during the Cold War this conflict had no ramifications in inter-state or inter-block relations and remained almost dormant. Since the beginning of 1990s rising nationalism and irredentism hit the Caucasus region and culminated in new cycles of ethnic hatred and revanchisms. The disagreement around how the events in the Eastern Anatolia in 1915 should be defined and who the responsible party was gained a momentum in the 1990s and turned out very strategic problem for Ankara which now seemed resolved to become full member to the European Union (EU) in the 2000s. The TurkishArmenian Reconciliation Commission was a first concrete and deliberate attempt to go around the flagrant issue of genocide to normalize the bilateral relations between the two nations. Both parties were aware that they had long been stuck in a value-based conflict that erected an insurmountable barrier before lucrative commercial bonds and moreover before a constructive solution to the NagornoKarabakh problem which was likely to allow Russia to sneak in the regional politics. Hence, the idea of commission was cooked abroad and scrutinized by the Western governments - primarily Washington.

Although it could be taken a good precedent to Track II diplomacy, the results of this first initiative to reconcile two nations were disdainful. Track II diplomacy invokes unofficial dialogue and negotiation activities aiming at encouraging official echelons and masses to shift their perception on their position in the ongoing conflict and providing them with clues relating how to normalize the relationships. They are mostly supplementary processes that run in parallel with diplomatic rapprochement (Track I diplomacy) and in most of the cases, the onset of a more comprehensive and multi-channeled inter-communal dialogue so-called Track III diplomacy. However, Track II diplomacy can occasionally be discerned with the role it plays in hammering out diplomatic contacts between the parties which had long frustrated due to transaction costs; i.e., electoral costs of abandoning "iron will" not to forge dialogue with the other party. By and large, the Turkish-Armenian commission seems to have assumed such a role. As discussed below, this multilayered process of normalization has been framed within a larger inter-communal cognitive setting characterized by mutual apology and forgiveness. On the other side, conflicts can be categorized simply as those on material interests and those on values. Although solving both types of conflicts may require drastic cognitive changes by the parties, conflicts on values cannot be ended by dividing or sharing the resources as the subject of the conflict, or by bringing additional resources, or by offering awards/ punishment. As Burton and Dukes (1990: 21-22) pointed out, in most of the cases "value-based conflicts has nothing to do with sources; i.e., money, territory, oil; and scarcity of material resources may not be a currency in their analysis. It is very hard for one to prevent values entering into judgments;" yet it is not impossible at least. 
Reconciliation Under The Shadow... $\quad$ DEU Journal of GSSS, Vol: 16, Issue: 2

Indeed, as pointed out in this study, the experiment of Turkish-Armenian Reconciliation Commission (TARC) has shown us the limits of such social constructivist arguments establishing a symbiotic bond between structural and cognitive shifts by luring the attention to a third factor; the Diaspora. The other aim of this study is to put forth the significance and of course the limits of a larger surrounding structure that may have policy makers found affordable a process which is likely to be looming large into an open-ended reconciliation.

\section{RECONCILIATION AND RECONCILIATION COMMITTEES}

Despite the fact that in the past a bunch of commissions bearing the prefix of reconciliation have been established, the matter has remained problematic since reconciliation is mostly understood as a process rather than a specific technique among the others serving to the resolution of conflict, or an end-state on its own. According to Bar-Tal (2000: 351-352), following the formal termination of the conflict, "the representatives of the conflicting parties start to eliminate their perceived incompatibilities" -this is called conflict resolution process. However, conflict resolution forms only one of the phases of a longer process, i.e., reconciliation, which requires fundamental change in parties' perception of the conflict and peace. "Once the members of society identify a particular situation as conflictual, conflict becomes a reality" (Bar-Tal, 2000: 352). It is valid for the peaceful settings also. Mendeloff (2004: 355-380) stresses that reconciliation "takes place through a long-term process aided by public policies and actions that confront the conflict between persons, institutions or communities"1. He points out also the necessity for the parties to reach at a consensus on the means and conditions for a healty reconciliation. Yet, to the contrary of Bar-Tal, in Mendeloff reconciliation is not a comprehensive process including conflict resolution, or policies which are designed to unveil the truth and to restore justice. Reconciliation is not the precondition for, yet one of the objectives of the process along with peace and justice. With this standing, reconciliation, in Mendeloff, poses something altogether independent from the other processes.

Staub points out the tendency to accept reconciliation as a process through which former victim and perpetrator, or members of hostile groups undergo a psychological turn towards each other, relieve themselves from the shadows of the conflictual past, in sum, turn a new and white page, mostly with the motto "never again". According to Staub (2006: 868) and Gopin (2000), this process invokes in large extent individuating the other side, in other words, recognizing its humanity along with all merits and defects, and as a consequence, mutual acceptance that enhances the possibility of establishing constructive relationships. Gibson (2004:

\footnotetext{
${ }^{1}$ See for a contending view, Aletta J. Norval (1998). Memory, identity and (im)possibility of reconciliation: The work of the truth and reconciliation commission in South Africa. Constellations, 5 (2): 250-265.
} 
201-202) also can be categorized within those who understand reconciliation as a process because he underlines that "reconciliation can be measured up as a macro level phenomenon" and requires "long range data". In his study discussing the reconciliation process in the South Africa, he underlines that reconciliation is a process through which communication between the parties [races] intensifies thereby paving way for a greater understanding, mutual acceptance and ultimately "appreciation and exaltation of the value of [racial] diversity". With this dimension, according to Gibson, reconciliation is simply "extension of dignity and esteem" to the others through "understanding, trust and respect".

Reconciliation is mostly taken as a process whose dynamics can be observed in every sort of conflicts. Indeed, the identity of the parties to conflict may have decisive impact on the course of the relevant process. Wallensteen (2002: 70-78) classifies conflicts according to the parties and the goal for the sake of which they struggle; e.g. inter-state conflicts and intra-state conflicts either for territory or government - so-called conflict trichotomy. Simply inter-state conflicts on territory and government are conventional "incompatibilities" in international arena and they are generally settled through armed or dialogue-based diplomacy. Intra-state conflict are respectively more complicated, hence Wallensteen assigned two branches of his conflict trichotomy to those kind of incompatibilities. Intrastate conflicts on territory invoke separation or political autonomy matters and they are mostly in between two different ethnic groups. Intra-state conflicts on government may derive from inter-ethnic power struggle too, yet in most of the cases parties are from the same ethnic stock. In intra-state conflicts on government the struggle is commonly for acquiring resources at the disposal of state to mold the society, redistribute the material and non-material values among relevant groups and so forth; for this reason they have visible ideological overtones. Finally, the general tendency is to take intra-state conflicts as conflicts on "nation-building" since secessionism or irredentism connotes disdainful for international community which is concerned for the inflation of new-born states and its relevant problems.

The literature on reconciliation has tended to diagnose the dynamics, form and limits of the process by extracting lessons generally from intra-state conflicts. In other words, reconciliation literature mostly tends to take as its locus the nationbuilding processes daunted by ideology or identity-based conflicts that left their behind tragic legacies; e.g. mass graves, missing persons, rape victims, disable peoples, homeless families, infants and inevitably mutual hatred and fear. On the other side, the works leaning on reconciliation in inter-state conflicts are comparatively very rare since the matter is recognized as the subject of the main streamline, namely the discipline of international relation. However, it does not necessarily mean that the discipline of conflict resolution stands aloof from interstate reconciliation. To the contrary, it serves to diversification of instruments that can be employed in settling conflicts and reconciling sovereign states. 
Reconciliation Under The Shadow... $\quad$ DEU Journal of GSSS, Vol: 16, Issue: 2

It is primarily because there are some inter-state conflicts that began as of intra-state conflict or vice versa. Hence, the scope of reconciliation can easily expand even so as to encroach into the milieu of traditional approaches of international relations which observe classical tenets of international relations like security dilemma, balance or distribution of power, rational decision-making and so forth while analyzing inter-state conflicts. On the other side, reconciliation may imply a politico-military stalemate urging the parties to lower their expectations than to continue fighting; in other words, "both parties may be reconciled to futility and finality" (Whittaker, 2002: 8). Within the context of reconciliation the discipline bridges conventional diplomacy with problem solving techniques which some thinkers appreciate to be an alternative way to the Hobbessian logic prevailed in so-called anarchic international order. In other words, this discipline appreciates supplemental role and contributions of the subaltern diplomacy, e.g. Track II and Track III diplomacy giving initiative to, respectively, notable opinion leaders and anyone who shows interest.

\section{THE TARC AND RECONCILIATION}

The Turkish-Armenian Reconciliation Commission (TARC) can be defined as a Track II initiative to solve, or truly transform the protracted conflict between the two "states", rather than the two "nations". Indeed it is this qualification of the commission that makes it original and concomitantly defective. In retrospect there available some examples to, albeit long-term, reconciliation processes between formerly hostile states like Germany and France or Poland, Czechslovakia and Russia (Phillips, 1998; Feldman, 1993). Especially GermanyIsrael reconciliation is the best example that facilitates us to draw some lessons for the Turkish-Armenian reconciliation process. The two cases are similar in that both conflicts started between the governments of the majority and a minority within the same state (despite the differences in the levels of asymmetry between the parties) and continued later between the two sovereign states and the relevant diasporas. Although the German and Turkish positions regarding the responsibility of human costs during the violent phases of the conflicts are different -needless to say, the Jewish and Armenian positions are similar- the basic leitmotives driving their governments to take the initiative are similar; e.g. the will to normalize relations with the rising global powers, to adhere to the Western security community and to earn reputation to be democratic and civic society in international arena.

However, Germany's acceptance, from the scratch, of the Nazi regime's crimes against the Jews in Germany and in the countries under Nazi invasion during the war helped the German leaders run a well-balanced and long-term diplomatic strategy to normalize the relations with the Israeli state and the Jewish lobby in the US. As for the TARC, the initiative was not the fruit of a visible diplomatic flirt between the two states that lasted along decades, nor was it devised 
to fulfill straightforwardly the function its title denoted; e.g. reconciling the "nations" by urging them to confess, forgive and forget past crimes and end enmities. Indeed, this semantic flaw is the basic reason of its failure.

As mentioned before, in the relevant literature reconciliation is defined either as a process or an end. On the other hand, some deeds that can be thought as the very components of reconciliation are taken as separate processes completely independent from reconciliation. Dwyer, for instance, handles individually the talk of apology, forgiveness and reconciliation (Dwyer, 1999: 81-82). Indeed, particularly in inter-state reconciliation the process certainly contains official apologies and in rare cases the rhetoric of forgiveness having theological overtones. For instance, presidential apologies such as Japan's for atrocities in Korea during 35-year long Japanese invasion, Montenegro's for shelling of the Croatian historical city of Dubrovnik during the Yugoslav crisis, Clinton's for Western impotency to halt genocide in Rwanda, and the British Premier Blair's official statement of regret to the Irish people for the British government's inaction during the Potato Famine in the nineteenth century, Palestinian leader Mahmood Abbas' apology from the Kuwaiti people for the Palestinian support to the invasion of their country by Saddam's Iraq, Germany's apology from Namibia for the massacre of Herero people during the colonial rule (Marrus, 2006: 4; Mandac1, 2002) and so forth, are official initiatives to erase the marks of the past misbehaviors on the current generations and governments. Hence, forgiveness seems to be a more complicated and delimited process and understandably follows official apologies. Yet, Tavuchis (1991: 132) refers to the process to "collective apologetic speech", indeed a more inclusive concept that attaches two processes with each other by intermingling diplomatic apology and religious confession. In the same vein Tavuchis portrays the apologetic speech to be part of a "larger interactional frame including oral and non-oral cues" that makes apology more humane and amiable.

However, as Marrus (2006: 13) underlines, "sorrow and sincerity which play an important role in interpersonal apologies, are much less important in official versions". In other words, official apologies are pragmatic acts destining the shift of image in the presence of the international community as well as in the eyes of the litigant rather than a signal of preparedness for collective confession and mourning. Furthermore, in most of the cases they are desirable in terms of decreasing transaction cost for the underdog (weaker) party who anticipates that the reestablishment of bridges with the topdog (stronger) party might bring economic and political benefits. Consequently, the most tangible component of reconciliation seems to be realistically instrumental for all parties whereas as its most humanistic- or theological in some cases- component "forgiveness" seems to have reserved for apolitical groups like religious institutions, civil society organizations and even individuals which observe ethical priorities. Indeed, this completely challenges with just what conflict resolution strives to do by recognizing the interconnection between the three levels of Tracks and tailoring 
Reconciliation Under The Shadow... $\quad$ DEU Journal of GSSS, Vol: 16, Issue: 2

talented and respected mediators (diplomats, religious leaders, human rights activists etc.) outstanding roles.

Conflict resolution recognizes apology and forgiveness both as the components of the reconciliation and as the stations that would be visited subsequently in due course of the reconciliation process. Nevertheless in inter-state level it is not so likely for train to arrive at the involved stations. To the contrary in inter-state level the parties signal out their intention rather to normalize relations by mostly taking painstaking steps to communicate. For instance, the so-called pingpong diplomacy between US and China in the 1970s cannot be taken as a reconciliation process. If a reconciliation process is to start, the interlocutors are not to be the plenipotentiaries of the states or parliaments. Yet thanks to the amelioration of bilateral relations in the higher level some individuals and organizations may have readily access to media to express their opinions which challenge with the former official stand. However, it does not necessarily mean that the increasing plurality of the views about the issue will culminate in an official apology. To the contrary, in diplomatic level both sides may eschew from demands that the other side may find exaggerative or provocative in order to sustain the process of normalization. In other words, it is too hard to figure out reconciliation through the dialectology of inter-state relations, but possibly amelioration, normalization, rapprochement and even alliance. Even though political leaders may make gestures signifying that they hold in esteem the dignity of the other side, actually no party can afford political adventures that may cost their posts in their respective countries.

\section{DIASPORA: THE THIRD PARTY OR MEDDLER}

In contrast with the careful diplomatic acrobatics of statesmen, intellectuals, religious leaders, human rights activists inside or outside and particularly diasporas may tend to take the advantage of diplomatic openings, or in most of the cases the reasons that drives the statesmen to engage in diplomatic normalization, and push for further action. Needless to say, their chances of success depend primarily on their bargaining power with their respective governments which stems from their ability to manipulate the masses inside and international support. Diasporas are inherently the most advantageous groups among others for some reasons. According to Sheffer (cited in Dufoix, 2003: 21) "diasporas are ethnic minority groups of migrant origins residing of acting in host countries but maintaining material links with their homelands". As for the argument of advantage, it is related to the discussions about the "true" and "false" diasporas. Safran (2004: 9) argues that "the diaspora phenomenon was undertheorized" because the relevant literature found the required conditions only in a limited number of transnational minority groups like Jews, Armenians, 
Chinese and Indians ${ }^{2}$. However, there are some other writers like Sokefeld (2006) who try to expand the definition so as to cover some other minority groups like Kurds, Alawis, Kashmirees, Taiwanese, Sikhs and so forth. However, Safran (2004: 10) warns us by underlining that the extension of the label all group of expatriates may inevitably reduce the concept to a useless metaphor.

Dufoix (2003: 21-22) notes that some writers are adamantly loyalty to the demographic criterion. For instance, according to Lacoste (cited in Dufoix, 2003: 22) "diasporas can be recognized by the dispersion of the major part of a people". In other words, those who immigrate should outnumber the population living in the homeland. Hence, the Chinese population in Southeast Asia (around 20 million) or Indians in the US cannot be thought as a diaspora. According to this criterion there are five "true" diasporas in the world; Jews, Armenians, Lebanese, Palestinians and Irish. The striking fact here is that of approximately 11 million Armenians in the world only 3.5 million lives in Armenia. Understandably in terms of the diasporahomeland population relationship Armenians are very different from Indians or Chinese. All authors assume that diasporas generally concern about the homeland's prosperity and security. However this is a one-dimensional view since most of the writers ignore the fact that China's concern for the Chinese minority scattered in the Southeast Asia or in the US and Israel's concern for the Jewish community in the US should be asserted through different perspectives. In other words, the differences in capacity of transnational minorities to influence their respective countries of origin or the hosting state and their place within the bilateral relationship between the hosting state and home-state are different issues. The Armenian and Jewish diasporas are unique from this aspect. For instance, although it is the smallest among the former Soviet republics, Armenia has remained to be the largest per capita foreign aid recipient in the region, mostly depended on the remittances from the diaspora in the North America and Western Europe (Ishakian, 2008).

Sokefeld (2006: 269) refers diaspora to a transnationally imagined community whose features can be diagnosed with the help of theories on social movements and sees all transnational minority groups as potential diasporas as far as they have political opportunities, mobilizing structures and they tend to develop frames through which they cognize their societal position in a wider environment. This liberal view envisages that diasporas can appear solely on democratic societies facilitating those groups with structures to organize themselves an exert influence on domestic or even international politics. Yet in the relevant literature diasporas are thought to be the communities which act as if they will never be the part of the hosting society even if the latter is highly democratic one. Furthermore, frames are check valves which their communal leaders deliberately create and

${ }^{2}$ By the way, Safran follows a mild course by accepting Chinese, Indian, Kurdish, Turkish, Greek, Sikh, West Indian, Cuban, Tibetan, Kosovar Albanian, Croatian and Serbian communities dispersed in foreign countries as diasporas. 
sustain to cushion their fear of assimilation into the larger society and to maintain communal solidarity. Sokefeld (2006: 270) defines frames as "specific ideas that fashion a shared understanding for a social movement by rendering events and conditions meaningful... and that transform certain conditions into an issue that help to define grievances and claims, legitimize and mobilize action".

Identity, for instance, is an indispensible basic [master] (paraphrased from Sokefeld) frame for diasporas. However, ideas regarding communal roots, history, the destiny, collective suffering and even class belongings all relevant to the identity again, may be the basic frames. This classification is in line with Cohen's categorization of diasporas (cited in Dufoix, 2003: 22-23) according to their primary identity; e.g. victim (Jews, Armenians, Africans and Palestinians), labor (Indians), trade (Chinese), cultural (the Caribbean) and imperial (British, French, Spanish and Portuguese in ex-colonial areas). Needless to say, the first group of diasporas distinguish themselves among the others because of their constant appeal to the discourse of victimhood that help them to earn sympathy and support of the outsiders. Yet, at the same time, in victim diasporas, the basic frame is respectively more unbending and consequently it may be non-adaptive of the climate of international politics. Especially when expatriates outnumber and they are comparatively more prosper, secure and politicized than, the population of the home-state, the diaspora may turn into a decisive actor, a supportive third party or a meddler determining the course of relations of the home-state with the other states particularly the ones with which it is at daggers drawn.

Then how can a [victim] diaspora play constructive or distortive role in the course of normalization of relations? Diasporas commonly concern with the bilateral relations between the host-state and the home-state. Laguerre (2006: 1820) argues that the informal component of diasporic politics takes many forms. Diaspora politicians may broker between the hostland and homeland, they may act as informal government advisors or influence peddlers providing homeland government officials with access to hostland government, as transnational activits and eventually formally as homeland government officials in hostland government. Although assumed an instrumental role in the relationship between host and home states in most of the cases, diasporas' role, position and impact on the home-state's domestic as well as foreign policies may change. It is generally accepted that home-states occasionally use diaspora for diplomatic and economic help particularly for remittences, sometimes they may resent the interference of diasporas in their internal or foreign affairs. As mentioned before, they may be more militant or be considered as acting on behalf of the host-state's interest. Moving from the example of the Haitian diaspora in the US, Laguerre (2006: 4953) puts forth five different models regarding home-state-diaspora relations thereby providing us with some clues to what extent this community of expatriates' matters. 
Firstly the reincorporation model refers to a political setting in which home-state finds repatriation of migrants (dediasporization) beneficial due to some economic and demographic reasons. Secondly, ethnic model implies diaspora's reconnection with the home-state to reinforce its political status in the host-state particularly around the issues like cultural rights. The third one, in the economic model, diaspora is thought to be supplemental or in some cases like Armenia, vital for economic survival of the home-state. The fourth, the opposition model involves the situations in which home-state and the diaspora come at loggerheads. In several cases one of the parties is a government-in exile supported by the diaspora members and international actors which tries to overthrow the home-state government. There may be some other compositions as well; for instance, the diaspora may extend its support to the opposition but continue to abstain from obviously challenging with the incumbent political leaders; or the parties may temporarily or constantly have contending priorities over specific issues. The fifth one is the transitional model. It invokes "the blurring of boundaries between [home]-state and diaspora, the expansion of nation, its transformation into a transnation". In this model, diaspora may turn into a province or department of the home-state or visa-versa, the nationality-citizenry difference becomes meaningless and nation outgrown the nation (home)-state.

Some writers argue that conditions of globalization enhance the possibility of transnations blurring diaspora and home-state interest division (Cohen, 2008; Atabaki and Mehendela, 2005). On the other hand, not only globalization but also extremely one-dimensional dependence of home-state to its diaspora may evaporate the borders between home and diaspora politics too -by the way, that immigrant group is extremely dependent on home-state is not an original, unprecedented phenomena. For the latter, this dependency costs the erosion of sovereignty and internal democracy in some aspects. Firstly, because home-state government has to take into account rather the priorities of a community transcending its own citizens as the voters whom they must be accountable to. Secondly, the home-state population may not be ethnically or culturally homogenous and dependency on diaspora may prevent home-state governments to be responsive to democratic demands of the relevant groups, the worse it may fan ethnic conflicts. Thirdly, as Sheffer (2003: 204) argues, "diasporas are far from always being supportive of homeland". For some emotional factors home-state and diaspora relations may deteriorate. Furthermore, diasporas may so extensively integrated into the host-state that they may show a partial loyalty to the host society. For instance, although they serve in the armies of the host-state, diasporans rarely run to the aid of their fighting kins. Fourthly, and most importantly, diasporas tend to cognize every social or political event through the lenses of the prevailed master frame, whereas home-states as sovereign units may have not such a luxury. Diaspora politics is highly emotional and even sometimes so militant particularly when the matter involves subjects demarcated by the master frame. 
Reconciliation Under The Shadow... $\quad$ DEU Journal of GSSS, Vol: 16, Issue: 2

The rest of this study is reserved to the Armenian diaspora's consistent stand toward the TARC mainly with the help of the discussions in the diaspora media -without appealing to the secondary sources- in the US. Although there is no enough space to analyze in detail the conditions that prepared a ground for the establishment of the commission, the arguments of the diasporan notables that reflect the logic of the diaspora's rejectionism is expected to illustrate the political environment where the developments took place. Secondly, this vivid debate is supposed to reflect how the Armenian diaspora ignored not only the home-state's political priorities but also the niceties of the regional politics as well as the mediation originated from the host-state and turned this timid diplomatic rapprochement into a showdown. On the other hand, the process confirms how difficult to run a reconciliation process between the two nations by semi-official plenipotentiaries and it hints that reconciliation may be possible as far as the two states continue to normalize their relations independent from the diasporic mortgage since the latter is always insistent to convey all sort of matters to the altar of victimhood.

\section{THE TARC CASE}

Although disrupted due to historical and geopolitical problems the postCold War Turkish-Armenian relations have never ruptured in reality. Rather than dealing with the value-based aspects of the conflict, the parties preferred to use a bunch of diplomatic platforms to sustain their bilateral relations progressing in snail's pace. Consequently, in large extent reconciliation remained as personal matter. For instance, Zoryant Institute singled out the individual initiatives for dialogue between the two nations as follows; Y1lmaz Güney, famous actor and movie director who is known with his leftist political stand, called the Turkish politicians to leave their denial policy during the Permanent Peoples' Tribunal ${ }^{3}$ held in 1981 in Paris, to which the institute was one of the sponsors. Another is Dr. Levon Marashlian, Armenian Professor of History who attended the Eleventh Turkish Congress of History in Ankara in 1990. ${ }^{4}$. Professor Taner Akçam and Vahakn Dadrian were also the academicians who started a dialogue in the 1990s which many academicians in Turkey found disdainful since the latter is known

\footnotetext{
3 The Permanent Peoples' Tribunal is an international opinion tribunal, independent from any state authority dealing with violations of human rights. The Tribunal was founded in June 1979 in Italy by succeeding the former Russell Tribunals I and II or the International War Crimes Tribunal for the war crimes committed against the Vietnamese people.

${ }^{4}$ The text of his speech and his exchange with the other academic attendants during the conference such as Justin Mc Carthy, Salahi Sonyel, M. Aktok Kasgarli, Andrew Mango is available online in his personal web site: http://www.glendale.edu/marashlian/Webs/lectureinAnkara1990.htm
} 
with his firm stand on the events in $1915^{5}$. Although the serious accusations against himself Akçam who allegedly discovered tragical story of an Armenian family saved by a Turk ${ }^{6}$ during the events began to believe that there was a strong possibility for establishing positive relations between the two nations in hostilities and continued his studies which remained outside the official as well as popular Turkish view about the events. His studies which challenged with official stand have been prayed by the institute. Another interesting incident was the visit of the monument of genocide in Yerevan in 1995 by the Istanbul Esenyurt Municipality Mayor Gurbuz Capan.

As for the diplomatic realm, the invasion of Nagorno-Karabakh remained as the source of friction between the two countries in the mid-1990s. However, in the OSCE Summit in Istanbul in November 1999, Turkish Foreign Minister Ismail Cem suggested, to the suprise of the attendants, mediation between Armenian and Azerbaijani parties. While Haydar Alijev, the President of Azerbaijan pondered the offer, the Armenian side was swift in repudiating it. On the other side, the idea of Caucasus Stability Pact which had been coined by Suleyman Demirel, former Turkish President, during the OSCE Summit provided the two parties with one of rare opportunities to come together officially. In the mid of February 2000, the Turkish and Armenian delegation along with others from the Caucasus republic handled some blueprints regarding stability and peace in the region which had been put forth by several think tanks and political circles, another attempt arising positive yet as understood later, exaggerated expectations indeed (De Waal, 2001). By the way, the statement of Turkish historian Halil Berktay, a co-founder of the Joint History Project, a civil initiative bringing historians from Balkan countries to remove mutual antagonizing remarks in history books, which pointed out to the necessity of reforming national education systems in the Caucasus as well to prevent "mutually hermetic insular hate narratives", (quoted in De Waal, 2001) was distinguishable. The meeting was adjourned with a declaration of commitment to continue the dialogue in the future, nevertheless it proved the futility of reconciliation unless the Caucasian nations tuned with each other on what the common problems among themselves were. Despite all formal and informal contacts thereof, it is hard to confirm that the two states had long been embroiled in a diplomatic flirt. Particularly that the establishment of the commission surprised

\footnotetext{
5 The lecture of Dadrian regarding Armenian Genocide at Harvard University on April 24, 2001, available online at http://ermeni.org/english/vdadrian_harvard.htm.

${ }^{6}$ The story of Haci Halil who hid a large Armenian family along a year in the penthouse of his house in Urfa inspired a movie directed and produced by Dorothee Forma. The movie was broadcasted by some TV channels in Netherlands also.

7 Demirel suggested a Stability Pact for Caucasus with the adherence of three South Caucasian countries plus their big neighbors; i.e., Russia, Turkey and Iran plus the European Union and the United States. On the other side, The centre for European Policy Studies, a Brussel-based think tank, offered a more courageous plan for the creation of a Southern Caucasus Community, modelled on the European Union.
} 
Reconciliation Under The Shadow... $\quad$ DEU Journal of GSSS, Vol: 16, Issue: 2

many demonstrates that even a diplomatic normalization had not been anticipated in a foreseeable future.

The Turkish Armenian Reconciliation Commission was formed in July 2001 and ceased its activities in April 2004. The body was composed of Turkish and Armenian ex-diplomats, academicians, activists and a retired Turkish general. In 2003, two retired diplomats; Gündüz Aktan and Özdem Sanberk along with the retired Lietunant General Sadi Erguvenc quitted and left the representation of the Turkish side to a group of delegates predominantly composed of academicians; Ustun Erguder, Vamik Volkan, Emin Mahir Balcioglu, Ahmet Evin, Ersin Kalaycioğlu, Şule Kut and İlter Turan, along with a retired ambassador, İlter Turkmen, thereby cleaning the delegation off its semi-official make-up. On the other side, the Armenian delegation was comprised of retired ambassadors; Alexander Arzoumanian (former foreign minister), David Hovhanissian, (members of the Armenian National Movement) the leading figures of Armenian activists from Russia and US; Antranik Migrarian and Van Krikorian from the Armenian Assemblies of Russia and America respectively.

The idea of creating a reconciliation commission came from David Phillips, a member of the influential think tank, Council on Foreign Relations, who saw such a body as the linchpin of an US-led mediation designed for peace in the Caucasus region. In Phillips' view, the acute lack of communication between the two nations could be overrun by Track II diplomacy which would bring together notable representatives who would drive their respective societies to nurture empathy against each other. The commission's work was expected to become a common denominator for civil society initiatives in two countries which would force the decision-makers to adopt a more benign stand in their mutual relations (Geukjian, 2005). However, the commission also announced developing blueprints for the Turkish and Armenian governments as one of its major objectives, thereby confirming that it took only the official decision-makers as true interlocutors.

From it scratch, the commission's work had been daunted by the constant verbal assaults coming from nationalist echelons of the Armenian society as well as the Armenian diaspora. The Armenian party complained that the Turkish members of the commission outnumbered the Armenians and that the Turkish delegation was heavily drawn from a conservative elite rather than independent civil society organizations in Turkey, who had gripped during their official tenure the classical Turkish thesis denying genocide. Even the non ex-officials in the Turkish delegation were portrayed as the person who did Turkish governments' bidding in the academic circles. Hence, it was claimed, as understood from its members' obvious adherence to, furthermore their role in its shaping, the official Turkish foreign policy, the Turkish delegation was here just to defend the conventional thesis of the Turkish state (Aghjayan, 2001). In the same vein, Armenian hardliners took the initial statements of some of the Turkish commissioners which reiterated the official thesis right after the inaugural session of the commission as a clear 
proof to that Turks struggled only for preventing pending genocide declarations in the Western parliaments. Some critics contended that the commission was the masterpiece of some circles who lurked for a time to convince the Armenian side to rule out the influential policy of getting acknowledged and repented which indeed managed to reap some outcomes recently, and instead adopt the policy of "forgive and forget"(Sonentz-Papazian, 2001).

The Armenian diaspora also thought that the Armenian delegation was not selected properly, because majority was drawn from those who had held important posts during the reign of the former President Levon Ter Petrosian who had never been in good terms with the Armenian diaspora abroad (Magdashian and Tadevosian, 2001) and claimed that consequently they could not represent the current political stand of the Armenian state ${ }^{8}$. It was claimed that Petrosyan had left the Armenian diaspora in the cold because he concerned that the community, more than twice the size of the population living in the Armenian proper, would have grasped the reins of the republic in the end. The diaspora played a pivotal role in the succession of Kocharian with enourmous financial resources in the presidential elections in 1998, in return, Kocharian pursued a non-lenient policy towards Turkey. On the other side, the Armenian diaspora boasted with its achievements in the international arena during the reign of Kocharian. During his 6.5-year tenure, only four countries had acknowledged genocide, yet, after Kocharian, seven countries recognized it. The diaspora spokespersons also underlined that in all those accomplishments full credit should be given to the diaspora rather than the two presidents and their aides (Sassounian, 2001b).

On 8 November 2000, the French Senate adopted a resolution recognizing disputed genocide, and two days later the head of the Armenian Church Garegin II signed a communiqué with the Pope Paul II which stated "the genocide of the Armenians was the prologue for many atrocities which have been committed over the past century" (Tedovisian, 2000). On November 15, the European Parliament demanded Turkey to restore diplomatic ties, end economic blockade and publicly admit the genocide. Days later, the Italian government adopted a similar resolution. It follows that the painstaking policy of Petrosyan towards Turkey had prevented a combined assault from the diaspora, but now with Kocharian rule this barrier seemed to have collapsed. Turkish government spokespersons condemned the parliament resolutions and accused Kocharian of "whipping up the international outcry" (Tedovisian, 2000) so as to endanger already fragile relation between Ankara and Yerevan. Meanwhile, Alexander Arzoumanian, later on the TARC member, was among the political throng criticized Kocharian's these clumsy policies.

8 This critique was made by the Director of the Institute-Museum of the Armenian Genocide, Lavrenty Barseghian to Asbarez Online on July 24, 2001. 
Reconciliation Under The Shadow... $\quad$ DEU Journal of GSSS, Vol: 16, Issue: 2

However, now Turkey could delay the genocide bills in the Congress or other parliaments lest they should endanger the talks. In fact, the nightmare of the rejectionist camp became real in the same month when the amendments on the draft report of the European Parliament pertaining Turkey which were suggested by Charles Pasqua and Andrie Brie, the leading political figures supporting the Armenian cause, were blocked by the French Christian Democrat reporter Alain Lamassoure (NTV-MSNBC, October 25, 2001). Despite the pressures from the Armenian diaspora and conflagrant debate during the Parliament sessions, European Parliament finally gave green light to continuation of process for Turkey's candidateship by entirely ruling out its previous reservations regarding the latter's formal recognition of genocide and ending the blockade of Armenia ${ }^{9}$. The action prompted a vociferous reaction among the Armenian communities in the world. The Armenian community in France particularly announced that Lamassoure, betrayed to the established political stance of the French state entailing genocide and alleged that his main concern was supporting the TARC, an illegal formation having neither public support among Armenians nor competence (Asbarez Online, October 11, 2001).

That the mediation for the establishment of the commission came from a prominent institution in the US alarmed Armenian diaspora also. Some critics took the involvement of the US State Department as a bad omen since the US governments had so far been pursuing very a painstaking policy towards Turkey in the matter of genocide. That the reconciliation commission was promoted by the US government seemed to have diluted the pro-Armenian congress group as well. Professor Marashlian warned that the US congressmen who welcomed the establishment of the TARC and called the Armenians stay united in their attitude opposing the commission. Simultaneously, the Armenian National Committee (ANC), the influential lobby organization of the Diaspora convened with the Frank Pallone from the Congressional Caucus on Armenian Issue to obtain the guarantee that the commission would not affect the vigorousness of political pressure on the congress for pushing a genocide bill (Asbarez Online, August 16, 2001).

However, another pro-Armenian congressman Adam Schiff unveiled that the participation of the president of Armenian Assembly of America in the

\footnotetext{
${ }^{9}$ Members of the socialist parties in the parliament; i.e., Parti Des Socialistes Europeens (PSE), Parti Populaire Europeens (PPE) and Confederal Group of the European United Left (GUE), and some members of the European Parliament from France, Belgium, Italy and Greece signed a statement denouncing the drop of relevant notes which put before Turkey the conditions of recognition genocide and establishment of diplomatic relations with Armenia for further progress. Those parties had already attempted three times for the amendments, all were dispelled in the following sessions. Eventually, by a vote of 271 to 149, European parliamentarians rejected Amendment 12, proposed by 45 deputies, which called Turkey to take a decisive step for normalizing its relations with Armenia by recognizing genocide.
} 
commission confused many congressmen and led them to think that the attempt had a broad community support and furthermore enabled pro-Turkish congressmen to buy time for deferring genocide bills at least until the commission finalized its work. During his visit to Armenia, Schiff reiterated his opinion to that the composition of the TARC did not reflect the opinions of the wide section of the Armenian society, and that the initiative would remain futile unless the genocide issue be included in its agenda. However, after his reception by President Robert Kocharian, he confessed there were some differences between the diaspora and Armenian authorities on the matter and obliged to state that the communication either in state or private level was required to break the logjam of dialoguelessness between the two countries (Asbarez Online, August 17, 2001). Another diplomatic support to the commission came from the US ambassador to Yerevan Michael Lemmon too (Asbarez Online, August 18, 2001).

On the other side, the commission abstained to provide detailed information about its agenda and content of its deliberations, another disturbing point as well. Actually, the Armenian commissioners had already disclosed that they had agreed in principle not to make individual public announcements about the agenda or the content. Concomitantly, the commissioners maintained their discreet stand and refused to unveil the deliberations with their Turkish counterparts after they returned home from the first meeting of the commission in Istanbul, thereby failing to lift the cloud of suspicion regarding the actual objectives of the commission.

However, the later statements of some Armenian delegates signaled the prevailed mood of repentance in the Armenian team well probably due to the pressure of the Armenian opposition and the diaspora. For instance, Arzoumanian pointed out that 'one of their objectives was [just] to try to present a package of proposals to the two governments which would be free to accept or throw them into the trash bin'. Simultaneously Foreign Minister Oskanian too, admonished the Armenian delegation to evaluate carefully the pros and cons of the commission's six-month activity. Reportedly, the tensions surfaced in the first session of the fourday meeting of the commission in New York on 18 November 2001 when the Turkish team fell into a row with the Armenian members on the matter of commission's role in liquidation of the established Armenian policy of recognition, and escalated upon the Armenian side's threat of withdrawal in the case that the commission disrupted or harmed the recognition efforts as the recent European Parliament act proved. It follows that the Turkish side stepped back and accepted the citation of several matters regarding international recognition in the joint concluding statement.

The statements of the Armenian diaspora's notables demonstrated that the Armenian party took reconciliation as a one-way avenue denying empathy with the other party. For instance, the diaspora reacted to the quotation of the remark of Elie Wiesel, prominent Holocaust survivor, in the dailies defining the event as a miracle 
Reconciliation Under The Shadow... $\quad$ DEU Journal of GSSS, Vol: 16, Issue: 2

(Sassunian, 2001b; Frantz, 2001). On the other side, the critics alleged that the commission seemed to have tailored itself the role of creating empathy as understood from the remarks of the Turkish commissioner Volkan emphasizing Turkish sufferings in 1915. In the same vein, in a letter to the editor of New York Times, Professor George Balakian (2001) contended that "it was not incumbent upon the Armenians to understand Turkish suffering during the World War I any more than it was incumbent upon Jews to understand German suffering during World War II". Hence, the Armenian opposition continued to retain the conventional view that the Armenians had nothing to do with the Turkish casualties or other relevant outcomes of the armed conflicts in the Ottoman state in the beginning of the twentieth century.

On August 24 Archibishop Oshogan Choloyan, the Prelate of the Armenian Apostolic Church of the Eastern US and Canada repeated the circulating thesis to the grounds that the commission would play into the hands of those who wanted to disunite the Armenian nation and called the Armenian commissioners not to exclude the genocide issue from the agenda of the commission if they wished to do something beneficial for the Armenian cause. Although the Archibishop accepted the necessity of a dialogue which would first begin unofficially and tackle with respectively less important issues like economic and diplomatic relations, unveiled his concerns that the commission might cause to loss of what had been gained [in pursuit of Hai Tahd, i.e., genocide] international arena (Armenian Weekly, September 1, 2001). The following communique of the Church admonished the Armenian commissioners not to divide the nation and reminded the Turkish side that the Armenian community was prepared to forgive those who acknowledged and accepted their transgressions in the past.

On the other side, the Diocese of the Armenian Church of America in New York, the community having more positive relations with the leading Armenian business society especially, published a more moderate message. The statement reminded that "the events of the past history had long separated and estranged the Turks and Armenians by bitterness, acrimony and mistrust" and the impacts of genocide had been inherited by the following generations. However, the statement underlined, this new commission might provide a real opportunity to normalize the relations between the two nations, and the community would pray for its success (Armenian Weekly, September 1, 2001). Despite its positive approach to the TARC, the critiques of the opposition did not target directly this community but those who allegedly led it astray for "business matters" (Astarijan, 2001) from its true course regarding relations with Turkey ${ }^{10}$.

${ }^{10}$ Astarijan disclosed that Armenian businessman Hrair Hovnanian, chief and spokesman of the Armenian Assembly had made some remarks which irritated other representatives of the diaspora, during a meeting in White House upon the Turkish blockade of Armenia after invasion of Nagorno Karabakh. He quoted him as saying "I am a businessman. What do I know about politics? I dont know if the genocide has taken place or not. I'll leave that to 
When compared with the initial enthusiasm and flared disputes, the commission accomplished not so much in the end. Only development that is worth mentioning in terms of reconciliation literally was the parties' decision to appeal to a think-tank in 2002. During the meeting under the facilitatorship of David Phillips and Theodore Sorensen, previously one of aides of John F. Kennedy, the parties decided to ask a the New York-based International Center for Transitional Justice (ICTJ) the applicability of the 1948 Genocide Convention to the events at the beginning of the twentieth century, even though the report would be discussed in the commission behind closed doors. The Armenian party hailed the decision which seemed deliberately leaked out by Phillips, and announced that 'it would be a great political and military victory for Armenia' if the ICTJ experts conclude that the incidents of 1915 could be categorized as genocide. However, the Turkish delegation opposed to the citation of the term of "genocide" or Genocide Convention in the final statement of the commission lest it should challenge to the official position of the Turkish state. Finally, the content of the ICTJ report did not satisfy both parties. It disappointed the Armenian side by stipulating that the Genocide Convention had no any provision mandating its retroactive application. Yet, it infuriated the Turkish party by assigning a large space to "what if" aspect of the matter ${ }^{11}$.

Since the beginning the Armenian side demanded the lifting of the Turkish economic blockade without any precondition. However, Ankara objected any rapprochement unless Armenia evacuated the Azeri territory under its occupation and the Turkish commissioners did not desire this opinion to be placed into the statement, instead, they consented to the addition of a simple explanation that the parties accepted to bring a proposal to the Turkish government on the lifting of visa restrictions against citizens of Armenia. In the beginning of 2002, in compliance with the commission's recommendation the Turkish government relaxed the visa restrictions against Armenia, only tangible product of the work of the commission. Yet Ankara continued to keep its borders closed to Yerevan in solidarity with Baku. The Armenian side welcomed the decision in the expectation that the decision would buttress the commercial links with the two countries which had previously been conducted over Tbilisi or Moscow (Magdashian, 2002). Although some advocated that against all odds the commission opened a channel for communication and consequently mutual empathy between the two nations, the

the historians and researchers". He also accused Hovnanian of collaborating with the foe, by reminding his role in the so-called "Trabzon Project" with Turkish businessman İshak Alaton, and his representation of a foreign company, Armentel, in a lawsuit against the fatherland Armenia.

11 The report of ICTJ titled The Applicability of The United Nations Convention on The Prevention And Punishment of The Crime of Genocide to Events Which Occurred During the Early Twentieth Century (2002), available online at http://www.ictj.org/images/content/7/5/759.pdf (June 1, 2010). 
Reconciliation Under The Shadow... $\quad$ DEU Journal of GSSS, Vol: 16, Issue: 2

Turkish-Armenian relations have so far remained soured and the tensions continued to soar customarily during the spring months of the year; prior to April 24 , the commemoration day for the diaspora. By the way, the recent protocol between the Turkish and Armenian presidents in 2009 seems to have shared the same fate with the TARC, albeit it deserves a detailed analysis within the same framework indeed.

\section{SUMMARY AND CONCLUDING REMARKS}

In the conflict resolution literature "reconciliation" is generally taken as mostly a third-party inspired process to relieve suspended nation-building from the legacy of ethnic conflict. Hence, reconciliation invokes two major interrelated concerns. On the international plane, it involves preserving the territorial integrity of the political entities whose populations were heavily inflicted by ethnic, religious, cultural or ideological frictions and preventing possible spill-over in the neighboring area. On the domestic plane, it is related to eradicating the psychological elements that might stall the ongoing peace-building in which intercommunal trust is to be desperately needed. In other words, reconciliation is mostly involved with keeping a nation unified if it tends to disintegrate because of ethnic or other relevant disagreements.

However, the term reconciliation is also employed in some cases, including that of Turkey and Armenia or post-Second World War Germany and Israel, to define diplomatic rapprochements between two sovereign nations. I found this interchangeably usage of the concepts of reconciliation and diplomatic rapprochement excessively problematic from varied aspects. Diplomatic rapprochement connotes deliberate state acts in pursuit of specific foreign policy objectives and it inevitably invokes visible and affordable transaction costs (like loss of vote in elections) for both the parties. It may be a beginning to a robust partnership in economic relations and transparency and mutual understanding in security sectors to prevent particularly security dilemma and even to alliance formation. However, this process is policy-oriented and cannot be promoted beyond strategic partnership in which the parties might get their objectives and policies in tune with each other's over a number of issues.

The TARC case showed how the Armenian diaspora's insistence to see the process as a full-fledged reconciliation with all psychological, cognitive and even theological elements between "the Turks and Armenians" blocked a promising course of diplomatic normalization between "Turkey and Armenia". No suspect, the prefix "reconciliation" attached to the title of commission led to some serious misunderstandings in the Armenian diaspora and understandably urged it to drag the issue into the ethical and theological waters of reconciliation, just like described in the literature of conflict resolution. Yet, if one glances at the initial stand of the Yerevan government it is understood that the Armenian side, like the Turkish side, considered the commission as a non-official forum to avoid 
transactional cost which might be inherited in official negotiations to normalize bilateral relations despite the bleeding problems like Nagorno Karabakh. Unfortunately, the TARC attempt failed due to the objections of the Armenian diaspora to the timing and mission of the initiative, the commissioners, its nonpublic sessions and its likely outcomes which would certainly fall short of what it had long demanded from the Turkish state; e.g., an official confession, apology and if probable compensation.

The TARC also confirmed the unlikelihood of "Sulha" (Braithwaite, 2002: 4) or ultimate arbitration by a respectable third party between states which in general possess the luxury of doing their way by ignoring ethical and even normative premises- particularly if they are confident to that they have visibly superior to their rivals ${ }^{12}$. Even if the stronger party evaluates the opportunity costs and affords conveying the matter to platform of restorative justice it can continue to hold the privilege of ultimate say as to what to be restored. Marshal defines restorative justice as a process whereby "all parties come together to resolve collectively how to deal with the aftermath of the offence and its implications for the future" (cited in Braithwaite, 2002: 11). However, the process is based on free deliberation and a final democratic decision that may cost dearly to one of the parties. TARC case indicates that neither states nor victim diasporas are not so virtuous as to acquiesce to sacrificing their interest by pushing the limits of democratic deliberation. For instance, as discussed in this text, the Armenian diaspora remained adamant in its position regarding the 1915 events and conditioned any diplomatic opening with the Turkish state's acknowledgment of its responsibility in the events and its implications and refused the Turkish governments' pending proposal for the establishment of an impartial commission of historians for investigation of the event. As for the Turkish party, the Turkish commissioners did allow only some citations in official declarations simply confirming that there exists a problem of recognition between the parties thereby postponing the issue to an uncertain time.

The logical conclusion that can be drawn from the discussion thereof is that master frames form as serious obstacle as state interests before reconciliation the parameters of which is unfolded by the discipline of conflict resolution. Another logical conclusion is that diplomatic rapprochement is the best way before furthering the process up to the level of reconciliation -if the parties amiably believe its necessity of course. The TARC case hints that reconciliation requires a

${ }^{12}$ Sulha is an ancient Palestinian institution of restorative justice still practiced in Galilee area. It is based on mediation of respected persons between the family of offended and offender. The parties may consent on leaving to the mediators the ultimate decision regarding the way and severity of punishment. 
secure environment in the largest extent, much beyond the lack of armed confrontation. First of all, reconciliation theoretically starts with the cease of hostilities and the process will be more sustainable as long as the persons who committed crimes, or turned a blind eye during the conflict are alive, within the reach and repentant. This posturing is probably valid for inter-state as well as intrastate reconciliation as the German-Israel relations confirms.

Secondly, inter-state reconciliation may be plausible in a societal environment much beyond that of the conventional society of states, probably within a security community, as defined by Deutsch, or in a different type of conglomerate of states. It seems that reconciliation between sovereign states might be taken as unprecedented, however on the other side, the European Union (EU) may be taken setting a good evidence to that it is not unthinkable. Yet, rather than spirituality, common material interests were what propelled the nineteenth century's ardent rivals to form a collectivity that can be categorized currently as "community." Nevertheless, the EU is a sui generis case; yet at least it signifies that inter-state reconciliation can only be understood within a basic frame of "community membership" -a new aspect that deserves a more detailed analysis indeed.

\section{REFERENCES} Weekly.

Aghjayan, G. (21.07.2001). A reconciliation based on denial. Armenian

Astarijan, H. (28.07.2001). The illegal child. Armenian Weekly.

Atabaki, T. and Mehendela, S. (Eds.) (2005). Central Asia and Caucasus: Transnationalism and diaspora. London-New York: Routledge . York Times.

Balakian, P. (16.07.2001) Letter to the editor of the New York Times. New

Bar-Tal, D. (2000). From intractable conflict through conflict resolution to reconciliation. Political Psychology, 21 (2): 351-365.

Braithwaite, J. (2002). Restorative justice \& responsive regulation. Oxford: Oxford University Press.

Burton, J. and Dukes, F. (1990). Conflict practices in management, settlement and resolution. New York: St. Martin Press.

Cohen, R. (2008). Global diasporas. London-New York: Routledge.

De Waal, T. (02.03.2001). "Recipes for stability in the Caucasus". Institute of War and Peace Reporting (IWPR), CRS Issue 72. http://iwpr.net/reportnews/recipes-stability-caucasus, (23.09.2010).

Dufoix, S. (2003). Diasporas. Berkeley: University of California Press. 
Dwyer, S. (1999). Reconciliation for realists. Ethics and International Affairs, 13 (1): 81-98.

Feldman, L. G. (1999). The principle and practice reconciliation in German foreign policy: Relations with France, Israel, Poland and the Czech Republic. (Royal Institute of) International Affairs, 75 (2): 333-356.

Fox, J. and Sandler. S. (2004). Bringing religion into international relations. New York: Palgrave.

Frantz, D. (10.07.2001). Unofficial commission acts to ease TurkishArmenian enmity. New York Times.

Geukjian, O. (2005). Book review, David L. Phillips, unsilencing the past: Track two diplomacy and Turkish-Armenian reconciliation. Peace, Conflict and Development, 7: 314-320.

Gibson, J. L. (2004). Does truth lead to reconciliation? Testing the causal assumptions of the South African truth and reconciliation process. American Journal of Political Science, 48 (2): 201-217.

Gopin, M. (2000). Between Eden and Armageddon: The future of the world religions, violence and peacemaking. Oxford-New York: Oxford University Press.

Ishkanian, A. (2008). Democracy building and civil society in post-Soviet Armenia. London-New York: Routledge.

Laguerre, M. S. (2006). Diaspora, politics and globalization, New York: Palgrave MacMillan.

Magdashian, P. and Tadevosian, A. (18.11.2001). "Troubled diaspora homecoming", Institute of War and Peace Reporting (IWPR), CRS Issue 110. http://iwpr.net/report-news/armenia-troubled-diaspora-homecoming, (23.09.2012).

Magdashian, P. (11.02.2002). "Travel to Turkey eases", Institute of War and Peace Reporting (IWPR), CRS Issue 115. http://iwpr.net/reportnews/armenia-travel-turkey-eases, (23.09.2010).

Mandac1, N. (2002). Is Montenegro the next?. Perceptions, 6 (4): 79-96.

Marrus, M. R. (2006). Official apologies and the quest for historical justice. (Occasional Paper, No. 111). Toronto: University of Toronto, Munk Centre for International Studies.

Mendeloff, D. (2004). Truth seeking, truth-telling, and post-conflict peacebuilding: Curb the enthusiasm. International Studies Review, 6 (3): 355-380.

Norval, A. J. (1998). Memory, identity and (im)possibility of reconciliation: The work of the truth and reconciliation commission in South Africa. Constellations, 5 (2): 250-265. 
Phillips, A. L. (1998). The Politics of reconciliation: Germany in East Central Europe. German Politics, 7 (2): 64-85.

Safran, W. (2004). Deconstructing and comparing diasporas. W. Kokot, K. Tololyan and C. Alfonso (Eds.) Diaspora, identity and religion: New directions in theory and research: In 9-29. London-New York: Routledge.

Sassounian, H. (19.07.2001a). Effort to reconcile with Turks causes discord among Armenians, California Courier.

Sassounian, H. (09.08.2001b). Reconciliation commission members deepen rift by lashing out critics. California Courier.

Sheffer, G. (2003). Diaspora politics at home abroad. Cambridge: Cambridge University Press.

Sonentz-Papazian, T. (21.07.2001). AAA to the rescue... How to restart the stalled vehicle of denial. Armenian Weekly.

NTV-MSNBC (25.10.2001). "Türkiye AP Raporundan Memnun", http://arsiv.ntvmsnbc.com/news/115099.asp

Sökefeld, M. (2006). Mobilizing in transnational space: a social movement approach to the formation of diaspora. Global Networks, 6 (3): 265-284.

Staub, E. (2006). Reconciliation after genocide, mass killings, or intractable conflict: Understanding the roots of violence, psychological recovery and steps toward a general theory. Political Psychology, 27 (6): 867-894.

Tavuchis, N. (1991). Mea Culpa: A sociology of apology and reconciliation. Stanford: Stanford University Press.

Tedovisian, A. (08.12.2000). "Armenian ghost haunt Istanbul”, Institute of War and Peace Reporting (IWPR), CRS Issue 61. http://iwpr.net/reportnews/armenian-ghosts-haunt-istanbul, (23.09.2010). Publications.

Wallensteen, P. (2002). Understanding conflict resolution, London: Sage

Whittaker, D. J. (2002) Conflict and reconciliation in the contemporary world. London-New York: Routledge.

Note: All articles and editorials excepted from Asbarez Online and Armenian Weekly is digitally available in the archives on the domain of the newslines located at asbarez.com and armenianweekly.com respectively. 